\title{
The Development of Shariah Audit Scope in Malaysian Takaful Industry: A Preliminary Analysis
}

\section{Noor Aimi Mohamad Puad}

To Link this Article: http://dx.doi.org/10.6007/IJARAFMS/v11-i3/11012 DOI:10.6007/IJARAFMS /v11-i3/11012

Received: 16 July 2021, Revised: 19 August 2021, Accepted: 02 September 2021

Published Online: 24 September 2021

In-Text Citation: (Puad, 2021)

To Cite this Article: Puad, N. A. M. (2021). The Development of Shariah Audit Scope in Malaysian Takaful Industry: A Preliminary Analysis. International Journal of Academic Research in Accounting Finance and Management Sciences, 11(3), 365-386.

Copyright: @ 2021 The Author(s)

Published by Human Resource Management Academic Research Society (www.hrmars.com)

This article is published under the Creative Commons Attribution (CC BY 4.0) license. Anyone may reproduce, distribute, translate and create derivative works of this article (for both commercial and non-commercial purposes), subject to full attribution to the original publication and authors. The full terms of this license may be seen at: http://creativecommons.org/licences/by/4.0/legalcode

Vol. 11, No. 3, 2021, Pg. 465 - 486

Full Terms \& Conditions of access and use can be found at http://hrmars.com/index.php/pages/detail/publication-ethics 


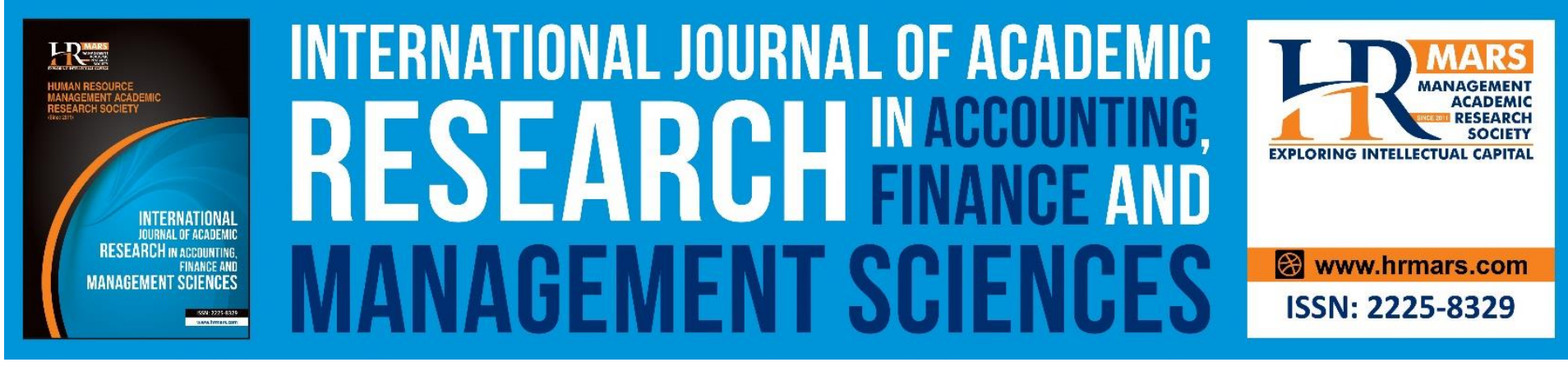

\title{
The Development of Shariah Audit Scope in Malaysian Takaful Industry: A Preliminary Analysis
}

\author{
Noor Aimi Mohamad Puad \\ Faculty of Management and Muamalah, Kolej Universiti Islam Antarabangsa Selangor (KUIS) \\ Email: nooraimi@kuis.edu.my
}

\begin{abstract}
Shariah auditing strengthens Shariah compliance while also enhancing the Islamic Financial Institutions' (IFIs) integrity. They arose as a response to the different natures and characteristics of IFIs including Takaful Operators. Failure to comply with shariah to the letter can have an impact on the legality and enforceability of Islamic finance transactions, as well as increasing financial and non-financial risks to IFIs. Due to that, it is critical for IFIs to have a thorough internal control system for Shariah compliant in order to effectively manage all Shariah issues. The focus of this study is to ensure that Shariah-compliance issues are adequately addressed, as Shariah non-compliance is a threat to all IFIs. Prior research reveals that there was a restrictive focus in the development of the audit scope as currently, the scope cover does not specifically cover financial statements nor the internal control systems relating to Shariah objectives. Thus, the aim of this study is to examine the scope of shariah audit developed by the auditors when conducting shariah audit. To achieve audit objective, semi-structured interviews were conducted involving selected committee members and shariah auditors of Takaful Operators. The study discovered that Takaful Operator addressed the requirement in the existing guidelines when developing their shariah audit scope. This study may provide relevant suggestions especially for the Takaful industry player in enhancing their shariah audit practice towards robust practice.
\end{abstract}

Keywords: Shariah Audit, Takaful, Scope

\section{Introduction}

Shariah auditing is a systematic process of gathering sufficient and relevant evidence to form an opinion on whether the subject matter, such as personnel, processes, financial and nonfinancial performance, is consistent with Shariah rules and principles that are widely accepted by the Islamic community, and to report to stakeholders. The role of Shariah auditing is far more complex and vital from an Islamic perspective, since it demonstrates the auditors' accountability not only to the stakeholders, but also to the Creator, Allah S.W.T.

Since the function of shariah audit have become mandatory in 2011, the function has evolved from providing shariah compliance services to providing an independent assessment 
MANAGEMENT SCIENCES

Vol. 11, No. 3, 2021, E-ISSN: 2225-8329 @ 2021 HRMARS

of internal control for any Shariah non-compliance risk in Islamic Financial Institutions. Shariah Governance Framework (SGF) introduced by BNM in 2010 has defined Shariah audit in para 7.7 as :"periodic assessment conducted from time to time, to provide an independent assessment and objective assurance designed to add value and improve the degree of compliance in relation to the IFI's business operations, with the main objective of ensuring a sound and effective internal control system for Shariah compliance" (BNM, 2011).

In 2019, Bank Negara Malaysia proposed a new definition of Shariah audit in a new policy document on shariah governance as following: "function that provides an independent assessment on the quality and effectiveness of the IFI's internal control, risk management systems, governance processes as well as the overall compliance of the IFI's operations, business, affairs and activities with Shariah" (BNM, 2019). AAOIFI's Governance Standard for IFIs no. 3 elaborates the objective of Shariah audit as:"The primary objective of the internal Shariah review (carried out by an independent division or part of the internal audit department) is to ensure that the management of an IFI discharges their responsibilities in relation to the implementation of the Shariah rules and principles as determined by the IFI's Shariah Supervisory Board (SSB)".

Understanding the meaning of Shariah audit is critical because it can influence how Shariah audit should be carried out. By merging the definitions of AAOIFI and SGF, an extensive description of Shariah audit may be presented. Apart from that, Shariah audit should take into consideration the components of Maqasid Al-Shariah in order to improve the function of Shariah audit. The preservation of wealth, which will result in the fulfilment of stakeholders' requirements, including the society as a whole, is an important part of Maqasid Al-Shariah in Islamic finance.

Therefore, the practice of shariah audit is expected to be comprehensive especially on the scope of shariah audit. However, it have been revealed in the past studies that there was a restrictive focus in the development of the audit scope as currently, the scope cover does not specifically cover financial statements nor the internal control systems relating to Shariah objectives (Alahmadi et al., 2017; Ginena, 2014; Shafii et al., 2013). There are two main objectives of the study:

R01.To examine the scope of shariah audit developed by the auditors when conducting shariah audit.

RO2.To propose the relevant scope of shariah audit based on the perceptions of the Takaful industry player

To this end, the main research question would be as following:

RQ1. To what extent does the development of shariah audit scope by Malaysian Takaful operators cover all the requirements in SGF and TOF?

RQ2. What should be included in the scope based on the perceptions of the Takaful industry player?

\section{Literature Review}

\section{Takaful and the Development of Takaful Industry}

Takaful derives from the root word kafala, which means "guaranteeing each other." It is based on the mutual insurance paradigm. Takaful was created to spread risk and help people who have suffered a financial loss. Members or participants in a group agree to jointly guarantee themselves against loss or damage under this scheme(Dikko, 2014). The entire 
MANAGEMENT SCIENCES

Vol. 11, No. 3, 2021, E-ISSN: 2225-8329 @ 2021 HRMARS

group would work with the incumbent to compensate him for his loss and offer him with financial assistance(Swartz \& Quartzer, 2010).

Basically, Takaful mechanism is based on the concepts of tabarru' (donation) and the intention (niah) to participate in the mechanism of pooling aid (AINemer, 2015). This tabarru' concept is the main distinguisher between conventional insurance and Takaful. From the Shariah perspective, tabarru' is a charitable contract which is normally unilateral in nature as opposed to contract of exchange; and that in the unilateral contract, the application of the rule of uncertainty is more flexible (Hassan, 2019). Tabarru' contract involves all forms of contract which are carried out with the aim of kindness and mutual help with the hope of obtaining a reward from Allah (S.W.T).

In general, the funds submitted for tabarru' should not be recovered (Irkhami, 2017). Tabarru' is also the core of the Takaful system, which allows the element of uncertainty under the Takaful concept (Ab. Rahim \& Amin, 2011). There is also a concept of risk distribution in Takaful. The conceptual difference between Takaful and conventional insurance is that risk is not exchanged in Takaful through contribution payments made to the operator, which means that the operator does not sell and the participant does not buy any risk cover (Hussain \& Pasha, 2011). Risk management also is encouraged by Islam and without a doubt Takaful ought to fall inside its ambit.

A study by Kasim et al (2015) proved that Takaful is a risk-sharing tool. In addition to that, Takaful depends on the idea of hazard sharing, not founded on the two-sided contract utilized in protection. The respective contract utilized purchasing and selling exchanges. The protected pays the premium in return for remuneration. As for Takaful, it depends on a onesided contract. Among the members, they are tied with the agreement of Tabarru' (donation) since the members commonly add to the Takaful hazard reserve with the expectation that the hazard reserve will be utilized to pay the cases. While between the members and Takaful Operators, the legally binding relationship is typically based on wakalah and mudarabah contract.

Takaful industry, particularly in the financial sector, plays a critical role in reducing risks and boosting global basic economic growth. The Malaysian Takaful industry, which began in 1984, was developed in three phases based on the Central Bank of Malaysia's master plan (Bank Negara Malaysia, 2005). The first phase, from 1982 to 1992, saw the establishment of the Takaful industry's infrastructure in Malaysia. The regional cooperation between Takaful operators was strengthened in the second phase (1993-2000). The third and final stage of the Financial Sector Master Plan (FSMP) (2001-current) aims to strengthen the legal, Shariah, and regulatory framework, as well as improve the competency of Takaful operators.

Malaysia's Takaful business has grown into a critical primary hub in the Malaysian economy, supporting Malaysia's status as a global Islamic financial centre. The main objective of developing Takaful plan in Malaysia was to comply to Islamic law and standards while also avoiding the three prohibited components (Riba, Maysir, and Gharar). The aim is to create and invent an Islamic alternative to conventional, which Muslims in Malaysia prefer. Presently, there are fifteen (15) Takaful Operators which get the license from Bank Negara Malaysia to operate.

\section{Empirical studies on Shariah Audit}

Given the Islamic financial sector's rapid growth, it is critical that it has an adequate 'check and balance' mechanism in the form of Shariah auditing adapted to its establishment's 
MANAGEMENT SCIENCES

Vol. 11, No. 3, 2021, E-ISSN: 2225-8329 @ 2021 HRMARS

aims and functions, Maqasid Al-Shariah, which literally means Shariah 'objectives of Islamic law' (Yaacob \& Donglah, 2012). Razak and Omar (2008) addressed the application of Shariah auditing in Malaysian IFIs and proposed that the Shariah audit function be implemented to improve Shariah assurance, as well as Kasim et al. (2009), who highlighted the gap between "the desired" and "the actual" practice of Shariah auditing in Malaysian IFIs. This is one of the first studies in Malaysia to look into practitioners' perspectives of what Shariah audit is and how the notion of Shariah audit works from an Islamic perspective.

These two studies were among those conducted prior to the issuance of SGF 2011, which made Shariah auditing mandatory. It's worth noting that the study conducted before to the publication of SGF 2011 focused on the idea for a single Shariah compliance component in any IFI. Prior to the issuance of the SGF, the focus of the research is on shariah audit practise, shariah audit human resources, issues and challenges and shariah audit awareness (Kassim \& Sanusi, 2013; Yaacob et al., 2013;. Mohd Ali \& Shafii, 2014; Kassim \& Zuraidah, 2013; Ab. Ghani \& Abdul Rahman,2015; Yazkhiruni et al., 2018).

Yazkhiruni et al., (2018) conducted the most recent study on Shariah audit practise, which used semi-structured interviews to investigate current Shariah auditing processes among IFIs (IFIs) in Malaysia. The study's findings revealed that the procedures are still being developed and improved, with a special focus on the standardization of the Shariah audit framework and guidelines for the design of the Shariah auditing audit programme. Recent studies on shariah audit have focused on determining the effectiveness of shariah audit while taking into consideration the drivers of effectiveness (Ab. Ghani et al., 2019; Zakaria et al., 2019; Al-Gabry et al., 2020; Al-Gabry et al., 2021)

Among the identified drivers include of the structure of shariah audit, the process of shariah audit, the requirements of shariah audit, management support, independency and objectivity, ecosystem, competency of the auditor and shariah audit charter. Recognizing the major drivers can help institutions improve their auditing practices by concentrating on the important aspects. On the same ground, it have been identified that majority of institutions are using risk based approach in conducting their shariah audit function(Ab. Rahman et al., 2019; Puad et al., 2020). Presently, the ideal decision for any Islamic Financial Institution is to implement risk-based auditing in the shariah audit function. By using risk-based approach, focus is placed more on higher risk areas as every institutions would have different risk appetite.

\section{Regulatory Framework on scope of shariah audit}

Shariah Governance Framework (SGF) and Policy Document of Shariah Governance (2019) The policy document on Shariah governance was introduced on 20th September 2019 and shall be effective starting 1st April 2020. In relation to the Takaful industry, this new policy will supersede a few other policy documents known as Shariah Governance Framework for IFIs issued on 22 October 2010 and Paragraph 13.5 of Financial Reporting for Takaful Operators issued on 2 February 2018. This policy document aims to further enhance the effectiveness of the implementation of Shariah governance and reinforce a closer integration of Shariah considerations into IFIs ' business and risk strategies. 
MANAGEMENT SCIENCES

Vol. 11, No. 3, 2021, E-ISSN: 2225-8329 @ 2021 HRMARS

Before the introduction of these policy documents, IFIs have to comply with the Shariah Governance Framework (SGF) which was introduced back in 2010. Commonly, there is not so much differences on the description for Shariah audit between the new policy document and SGF 2011. The new description for Shariah audit function is simpler and clearer which highlighted on the objective of having effective and quality internal control, risk assessment, governance and Shariah compliance. This is the same for the description of Shariah audit process, which emphasized on the need for establishing suitable audit methodology, audit plan, audit program and finally audit report communication to the board and Shariah committee.

Under SGF(2011), the scope of Shariah audit in SGF shall cover all aspects of IFI's business operations and activities as follows:

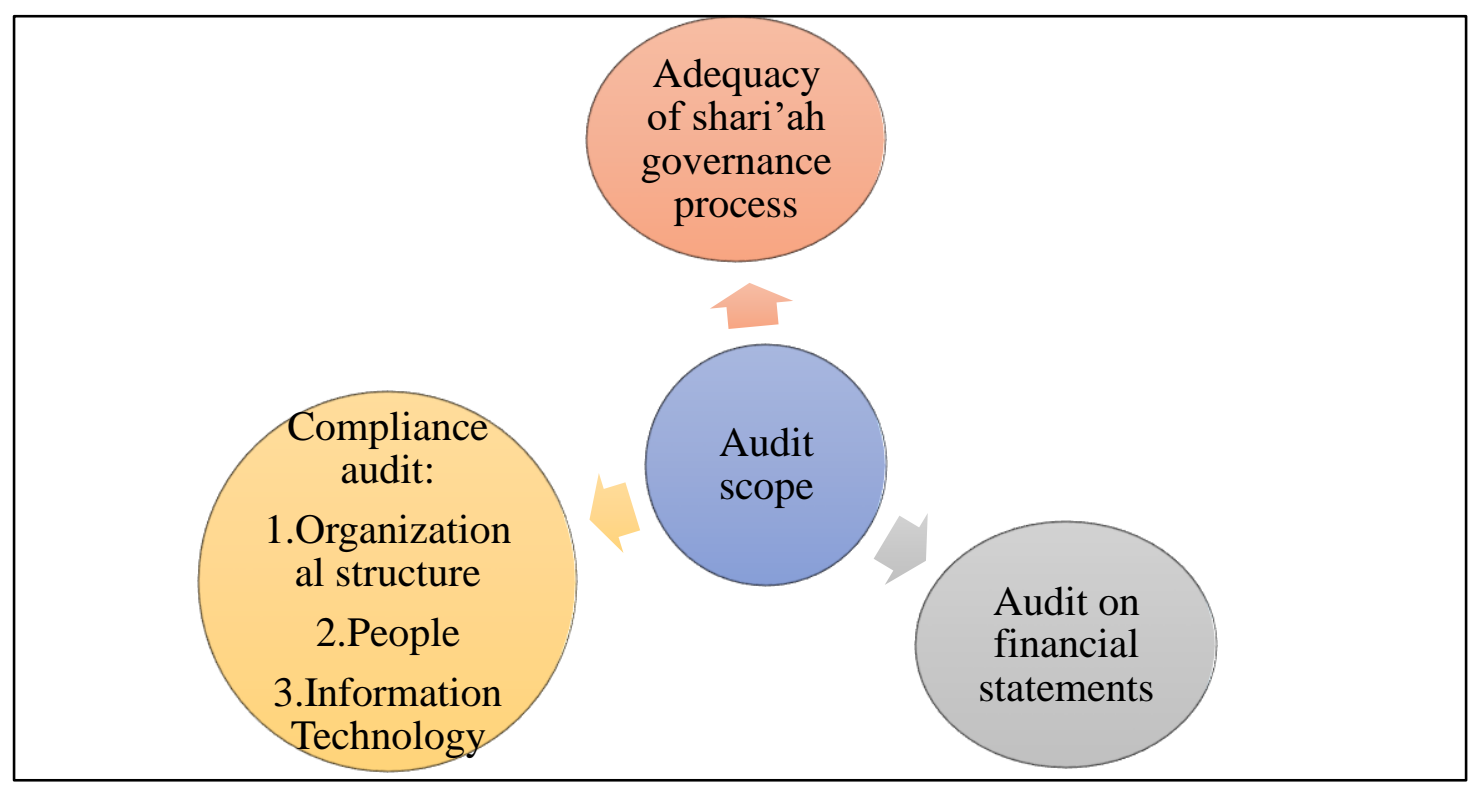

Figure 1.0 Audit Scope based on SGF

Sources: (SGF,2011)

It is very crucial to explore to what extent is the scope of Shariah audit covered by Takaful Operators as it will determine whether these institutions have already followed the available requirements or they have gone beyond that. A study done by Ab. Ghani and Rahman (2015) revealed that only $5 \%$ of Islamic banks conducted a Shariah audit on their financial statements. Most of them just rely on external auditors to review their financial systems which are focusing more on operational issues rather than Shariah issues.

\section{Takaful Operational Framework(TOF)}

Bank Negara Malaysia has introduced the Takaful Operational Framework (TOF) for the orderly growth of Takaful business, which provides certain parameters for the management of Takaful business. Among the objectives of this guidelines are to enhance operational efficiency of Takaful business; to build healthy Takaful funds which are sustainable; to safeguard the interests of participants; and to promote uniformity in Takaful business practices.

The Guidelines cover operational processes relating to Takaful and shareholders' funds. The requirement in TOF includes of setting up of funds, management of Takaful operations, management of operating costs and income of the Takaful operators, management of assets, 
MANAGEMENT SCIENCES

Vol. 11, No. 3, 2021, E-ISSN: 2225-8329 @ 2021 HRMARS

liabilities and surplus, and, rectification of deficiencies of the Takaful funds and disclosure and transparency.

Takaful operators shall establish an operational model that outlines the key policies, procedures and management's responsibilities in carrying out the Takaful operations. The operational model shall be based on contracts preferred by the Takaful operator and approved by the Shariah Committee. In setting out the policies and procedures, Takaful operators must ensure that the principles outlined in the contracts are appropriately operationalized.

In terms of segregation of funds, Takaful operators are required to establish and maintain separate Takaful funds in respect of family Takaful business and general Takaful business. Each Takaful operator shall establish and maintain a separate Takaful fund for its Malaysian Takaful certificates and for its foreign Takaful certificates. The Takaful funds for the family Takaful business shall be segregated into two further funds, namely Takaful protection fund and Takaful annuity fund.

Within the family Takaful funds, Takaful operators shall separately establish Participants Risk Fund (PRF) and Participants Investment Fund (PIF). Takaful operators shall maintain records of and properly allocate the assets, liabilities, revenues and expenses of the Takaful operations to the relevant funds. The method of allocation and the proportion of contribution allocated to the Takaful funds must be made transparent in the Takaful contracts.

In 2019, the revised version of TOF has been issued by BNM which aims to provide clarification in the use of various Shariah standards for Takaful models and structures namely: Tabarru', Wakalah, Mudarabah, Qard and Hibah. The new TOF also lays out criteria for enhancing internal controls over the development of additional Takaful funds. Under the revised standard, Takaful operators need to create a process for assessing the efficiency of additional resources and their long-term sustainability, ascertaining distinct pricing methodologies specific to distinct products, and considering, among others, distinct techniques of surplus distribution. This new TOF is hoped to enhance the governance of Takaful operators, including how Takaful funds are managed, to further protect the interests of Takaful participants.

In conclusions, this TOF is a regulatory framework which focuses on the operational part of Takaful to ensure uniformity in the practice of Takaful Operation. For auditors, this TOF is the main reference for them to perform the compliance audit and to ensure the operations of Takaful comply with all the requirements.

\section{Research Methodology}

A qualitative research approach was applied in this study to allow for the application of clarification, insight, discovery, and interpretation of the phenomena under inquiry. Qualitative research uses open-ended and flexible methodologies to assist researchers understand how individuals perceive the events under investigation and examine them from various perspectives(Merriam,2009). This approach was utilized for the present study because it allows for a more holistic understanding of the nature, context, and processes of shariah auditing procedures from the perspective of the participants. As a result, rather than "proving" or "disproving" allegations concerning the breadth of the shariah audit activity, the study's goal is to perform an in-depth analysis.

A structured interview was undertaken to acquire complete information and an understanding of the respondent's IFI's internal control and Shariah issues. According to 
MANAGEMENT SCIENCES

Vol. 11, No. 3, 2021, E-ISSN: 2225-8329 @ 2021 HRMARS

Weischedel et al. (2005), even if the interviewer is able to provide a quick explanation, indepth information cannot be obtained. A list of potential respondents was prepared based on their knowledge and experience of conducting Shariah audit in the Malaysian takaful industries. The data were collected from a total of 22 respondents. In the meantime, each respondent received a formal interview request by e-mail. Below is the table which illustrate on the details of the respondents involved in the interview sessions:

Table 1.0: Details of Respondents

\begin{tabular}{|c|c|c|c|c|}
\hline Respondents & Gender & $\begin{array}{l}\text { Highest } \\
\text { Qualification }\end{array}$ & Positions & $\begin{array}{l}\text { Years } \\
\text { experience } \\
\text { industry }\end{array}$ \\
\hline R1 & Male & Bachelor & Principal Auditor & $16-20$ years \\
\hline $\mathbf{R 2}$ & Female & Master degree & $\begin{array}{l}\text { Senior Manager, } \\
\text { Shariah } \\
\text { Department }\end{array}$ & $11-15$ years \\
\hline R3 & Male & Bachelor & $\begin{array}{l}\text { Senior Manager, } \\
\text { Internal Audit }\end{array}$ & $6-10$ years \\
\hline R4 & Male & Bachelor & $\begin{array}{l}\text { Assistant Manager, } \\
\text { Internal Audit }\end{array}$ & $6-10$ years \\
\hline R5 & Female & Bachelor & Audit Associate & $16-20$ years \\
\hline R6 & Male & Bachelor & $\begin{array}{l}\text { Manager, Internal } \\
\text { Audit }\end{array}$ & $6-10$ years \\
\hline R7 & Male & Bachelor & $\begin{array}{l}\text { Head of Internal } \\
\text { Audit }\end{array}$ & $21-25$ years \\
\hline $\mathbf{R 8}$ & Male & Bachelor & $\begin{array}{l}\text { Senior Manager } \\
\text { Shariah, Legal and } \\
\text { Secretarial, } \\
\text { Governance \& } \\
\text { Strategy }\end{array}$ & $6-10$ years \\
\hline R9 & Female & Bachelor & $\begin{array}{l}\text { Manager, Internal } \\
\text { Audit }\end{array}$ & $11-15$ years \\
\hline R10 & Male & Master degree & $\begin{array}{l}\text { Manager, Internal } \\
\text { Audit }\end{array}$ & $15-20$ years \\
\hline R11 & Male & Master degree & $\begin{array}{l}\text { Head, Shariah } \\
\text { Advisory, Research } \\
\text { and Training }\end{array}$ & $11-15$ years \\
\hline R12 & Female & $\begin{array}{l}\text { Ph.D. in Business } \\
\text { Law }\end{array}$ & Shariah Committee & $11-15$ years \\
\hline R13 & Male & $\begin{array}{l}\text { Ph.D. in Islamic } \\
\text { Finance }\end{array}$ & Shariah Committee & $11-15$ years \\
\hline R14 & Male & $\begin{array}{l}\text { Ph.D. in Islamic } \\
\text { Finance }\end{array}$ & Shariah Committee & $11-15$ years \\
\hline R15 & Male & $\begin{array}{l}\text { Ph.D. in Islamic } \\
\text { Finance }\end{array}$ & Shariah Committee & $11-15$ years \\
\hline R16 & Female & $\begin{array}{l}\text { Ph.D. in Islamic } \\
\text { banking and Finance }\end{array}$ & Shariah Committee & $11-15$ years \\
\hline
\end{tabular}


INTERNATIONAL JOURNAL OF ACADEMIC RESEARCH IN ACCOUNTING, FINANCE AND MANAGEMENT SCIENCES

Vol. 11, No. 3, 2021, E-ISSN: 2225-8329 @ 2021 HRMARS

\begin{tabular}{|c|c|c|c|c|}
\hline R17 & Male & $\begin{array}{l}\text { Master's degree in } \\
\text { Islamic Management } \\
\text { Banking and Finance }\end{array}$ & Shariah Committee & $11-15$ years \\
\hline R18 & Male & $\begin{array}{l}\text { Ph.D. in Islamic } \\
\text { Banking and Finance }\end{array}$ & Shariah Committee & $11-15$ years \\
\hline R19 & Female & Ph.D. in Law & Shariah Committee & $11-15$ years \\
\hline $\mathbf{R} 20$ & Female & $\begin{array}{l}\text { Ph.D. in Islamic } \\
\text { Finance }\end{array}$ & Shariah Committee & $11-15$ years \\
\hline R21 & Male & $\begin{array}{l}\text { Ph.D. in Islamic } \\
\text { Studies }\end{array}$ & Shariah Committee & $11-15$ years \\
\hline R22 & Male & $\begin{array}{l}\text { Ph.D. in Syariah } \\
\text { (Muamalat) }\end{array}$ & Shariah Committee & $11-15$ years \\
\hline
\end{tabular}

Sources: (Researcher,2020)

Structured interviews were conducted using a smartphone and a digital recorder. The interviews lasted between 1 and 1.5 hours. The respondents were assured at the start of the interviews that their identity and all information provided would be kept totally confidential. The recordings of the interviews were then transcribed in order to retrieve the data needed for the study. Regardless of the analytical methodologies and tools utilised, transcribing, according to McLellan et al. (2003), assists researchers in systematically organising and analysing textual data.

The data was then analysed using a phenomenological technique, which included interpreting and reflecting on the data transcribed. As a result, in order to gain a holistic comprehension of the significance of the interviewees' impressions of the study's ongoing occurrences (Alexis \& Vydelingum, 2007)

\section{Findings and Analysis}

This section will answer two main research questions followed by the analysis of discussions. The research questions are as following:

RQ1. To what extent does the development of shariah audit scope by Malaysian Takaful operators cover all the requirements in SGF and TOF?

Shariah Governance Framework (Audit of financial statements of the IFI) 


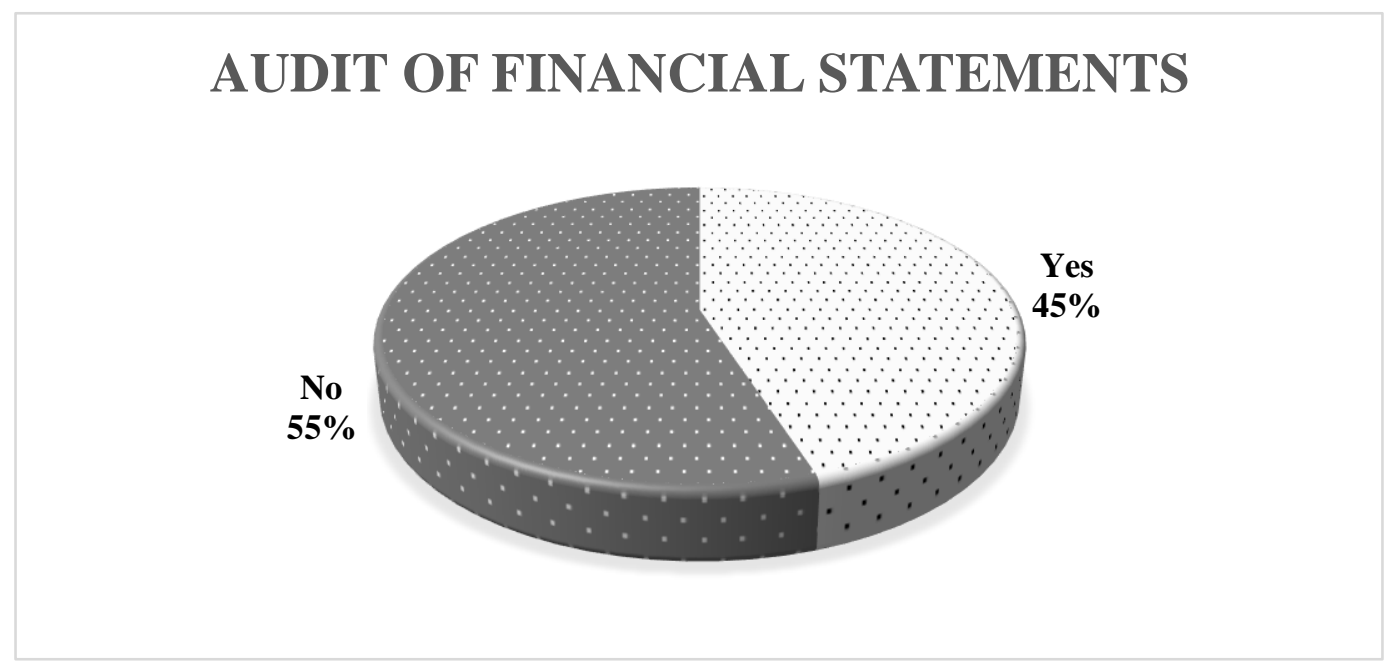

Figure 2.0 Percentage of Takaful Operators Which Developed Scope for Audit of FS Sources: (Researcher,2020)

Majority of Takaful Operators which is approximately about 55\% of Takaful Operators do not include the review of financial statements in their Shariah audit scope. This is because they rely on external auditors to check on their financial statements which is allowed in SGF. On the other hand, $45 \%$ of the operators perform audit on their financial statements and look into certain elements which can lead to potential Shariah non-compliance risk.

Normally, the auditors will look into areas which have Shariah concerns. Among the elements include Takaful surplus distribution, claim expenses and entertainment and investment. In some cases, the auditors will only review their financial statements if there are any issues raised by SC or BAC in the meeting during the planning stage. On the same ground, one of the Takaful Operators audit their financial statements because it is part of their audit universe of finance. Figure 3.0 below summarizes the elements of Shariah that have been audited by auditors based on their financial statements.

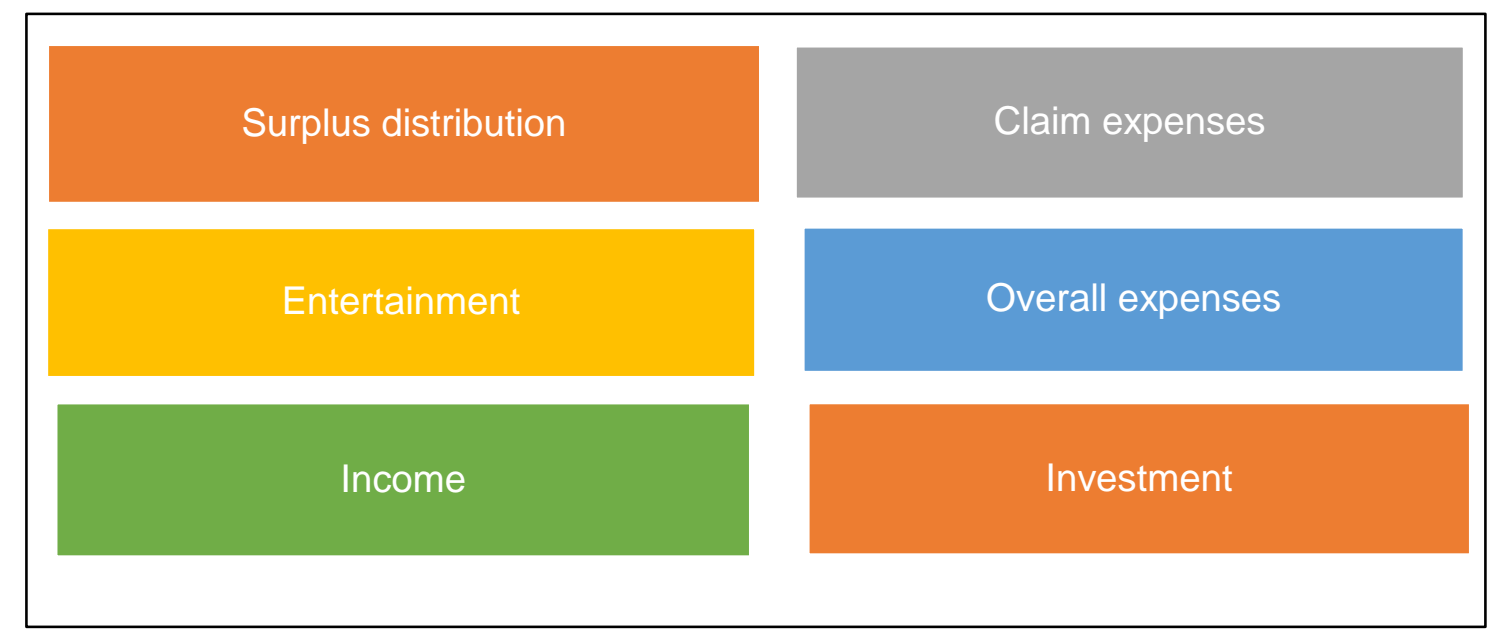

Figure 3.0 Elements of Shariah Issues in Financial Statements Highlighted by Auditors Sources: (Researcher, 2020) 
The word surplus in Takaful is the excess contribution to claims payments in the risk pool (Saha, 2010). According to Noordin (2013), currently there are at least three rulings issued by Shariah scholars on this issue. The first ruling is that both of the participants and the shareholders (or operators) may not have a legitimate claim to the Takaful's surplus. Secondly, participants are the only legitimate proprietor of the surplus and finally the other opinion validates the sharing, depending on ratios that vary according to the product line offered. Takaful Operators must implement their surplus distribution based on these three rulings and therefore these elements should be included in their audit scope.

The second element is claim expenses which is further defined as a formal request to the Takaful operator by the Takaful participant (policyholder) detailing the disaster that impacted him; and requested compensation as agreed in the Takaful Policy (Muhamat et al., 2017). On the other hand, fraud on Takaful claims occurs when the specific accident results in a formal claim procedure with additional economic implications for the non-existent damages. Fraud is one of the risks faced by the Takaful Operators. A study by Mohd Fauzi and Rashid (2016) revealed that there is a need for the Takaful industry in Malaysia to expedite action on claims to give stakeholders and the public more confidence with higher ownership by both Takaful operators and operators of the claims processing process and decisionmaking. Thus, Takaful claim procedures and techniques developed should be in accordance with the Shariah laws and regulations.

The third element is entertainment which includes the expenses for entertainment incurred by Takaful Operators. Among the examples for entertainment expenses include dinners for award achievement or family day or holiday rewards. Normally, these entertainment expenses would be for the agent of Takaful Operators. It is very important to ensure that these entertainment expenses are used for halal and Shariah compliant subject matters. The same goes for the overall expenses of Takaful Operators. The expenses of Family Takaful Operators and General Takaful Operators consist of refund contribution, Re-Takaful, depreciation, death claims, maturity of certificate, certificate surrender and part withdrawal (Billah \& Basodan, 2017). The distribution of expenses must be done in accordance with Shariah.

The next element is sources of income. All income for Takaful Operators must come from halal sources such as from wakalah fees or profit sharing from mudharabah contract or profit from investment. Takaful Operators should also maintain three types of accounts namely the Family Takaful Fund, General Takaful Fund and shareholder fund (Billah \& Basodara, 2017). An investment-related Takaful is generally a Family Takaful plan that combines investment with full coverage (Noor, 2009). In this investment-linked Takaful, Participants' contributions will be split into two portions. One part is to serve protection where the fund will be treated as a gift for a specific portion of the contribution. This part, as in the event of death or disability, is used to assist participants who need it most. The other part of the contribution concerns the purchase of investment-linked units. Thus, Takaful Operators must ensure that the investing is included as an option into the Shariah-compliant investment with a valid Shariah contract which at the same time could eliminate the issues of riba'. 
MANAGEMENT SCIENCES

Vol. 11, No. 3, 2021, E-ISSN: 2225-8329 @ 2021 HRMARS

Based on the elements described by the interviewees, there is still a gap between the

No. Issues

1 Distribution of profit and loss is made in accordance to Shariah principles

2 Accuracy of accounting transactions

Income from general Takaful and family Takaful is accounted for on cash basis and any receipts in advance are treated as liabilities

Expenses accounted for on accrual basis

Calculation of reserve is based on $1 / 365$ th

Cost of Retakaful is considered as a liability until contribution is fully paid

$3 \quad$ Zakat payment

No. Issues

1 Distribution of profit and loss is made in accordance to Shariah principles

2 Accuracy of accounting transactions

Income from general Takaful and family Takaful is accounted for on cash basis and any receipts in advance are treated as liabilities

Expenses accounted for on accrual basis

Calculation of reserve is based on $1 / 365$ th

Cost of Retakaful is considered as a liability until contribution is fully paid

3 Zakat payment

actual practices in the scope of financial statements with the elements discussed in the previous literature which should be addressed properly. Table 2.0 illustrates the gap of Shariah issues which have been highlighted by previous literature and should be included as a part of the elements in auditing of financial statements.

Table 2.0 Elements in Financial Statements that should be Addressed by Auditor Sources: (Abu Kasim, 2012; Bilah \& Basodan, 2017; Nahar, 2015)

The table above illustrates the gap between the actual practice as described by the interviewee and the scope proposed for this study on financial statements. Based on the table, it can be concluded that it would be better if Shariah auditors can conduct the Shariah audit scope on financial statements rather than just relying on the external auditors. The reason is because normally external auditors would be focusing on the operational part rather than the Shariah issues. Not all external auditors have expertise on Shariah and therefore auditing on financial statements should be considered to be put under the obligation of Shariah auditors. 
4.2 Shariah Governance Framework (Compliance Audit on Organizational Structure, People, Process and Information Technology (IT) Application Systems)

\section{COMPLIANCE AUDIT ON ORGANIZATIONAL STRUCTURE, PEOPLE, PROCESS AND IT}

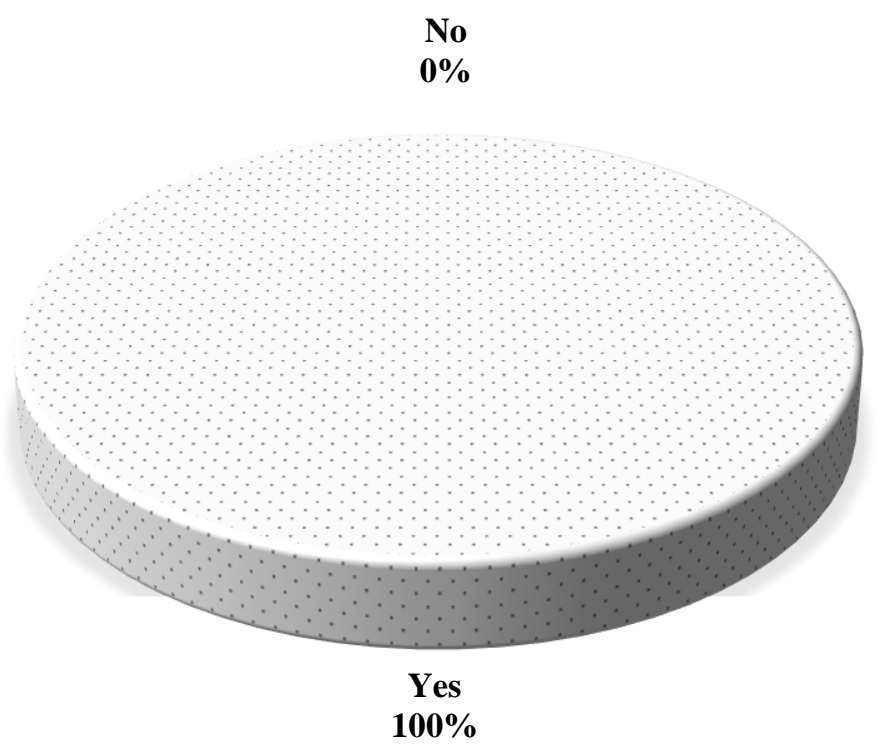

Figure 4.0 Percentage of Takaful Operators which Developed the Scope for Audit on Organizational Structure, People, Process and Information Technology (IT) Sources: (Researcher, 2020)

In terms of compliance audit on organizational structure, people, process and information technology application systems, based on interview, all operators did perform audit on these elements. One of the respondents mentioned that they cover all the scope in their audit, but the auditor did not agree with the term of compliance in front of the elements as for him, compliance is more like a checklist approach, which does not portray the objective of Shariah audit.

Normally, Information Technology is the system which reflects the implementation of the contract. For example, the percentage of wakalah fees. If it has been stated in the contract or proposal form that the percentage of wakalah fees is $40 \%$, then it must be reflected in the system as well. This is the example given by the auditor when they perform the audit on information technology.

For organizational structure, normally the auditors will check on the job descriptions and the functions for each of the departments. Sometimes, it happens that there is a confusion between the job function of compliance and risk management. The segregation of duties and the job scope for each function must be clarified from the start. In terms of staffing, normally the auditors will check whether they have the appropriate skills or not. The table 
INTERNATIONAL JOURNAL OF ACADEMIC RESEARCH IN ACCOUNTING, FINANCE AND MANAGEMENT SCIENCES

Vol. 11, No. 3, 2021, E-ISSN: 2225-8329 @ 2021 HRMARS

below summarizes the elements that will be reviewed by the auditors when performing this audit scope:

Table 3.0 Audit Elements for Organizational Structure, People, Process and IT

\begin{tabular}{lll}
\hline No. & Scope & Elements \\
\hline $\mathbf{1}$ & $\begin{array}{l}\text { Organizational } \\
\text { structure }\end{array}$ & $\begin{array}{l}\text { Reporting line, Job descriptions, Functions, } \\
\text { Authority, Responsibility }\end{array}$ \\
\hline $\mathbf{2}$ & People & Background, experience, skills, awareness, training \\
\hline $\mathbf{3}$ & Process & SOP, manual \\
\hline $\mathbf{4}$ & IT & System (Integrate with IT auditor) \\
\hline
\end{tabular}

Sources: (Researcher, 2020)

Usually, the compliance audit process is performed to ensure that an organization complies with legislative laws and guidelines for the provision of valid and reliable audit reports to all stakeholders especially on any Shariah issues. Based on the analysis of the respondents' answers, the majority of Takaful operators cover these four elements, but the practices adopted are different based on each Takaful operator's interpretation. Some might be more detailed, which means that the auditors look beyond the compliance aspect as what has been practised by Takaful Operator A. Since this second proposed scope has the word "compliance", it can be observed that Takaful operators have established this scope when conducting Shariah audit.

The findings reveal that normally Takaful Operators which adapt embed all auditors for their Shariah audit function model usually will cover this scope of audit in detail only if there is any Shariah issues raised by Shariah committee or by Shariah officers. For example, if there are any issues on the IT systems which miscalculate the rate of wakalah fees, then the scope would be established for this area. Otherwise, they will just follow the minimum requirement which is checking on the compliance. Some Takaful Operators also would apply a risk-based approach when deciding on the details of the scope that they plan to cover for the financial year. 


\section{ADEQUACY OF SHARIAH GOVERNANCE PROCESS}

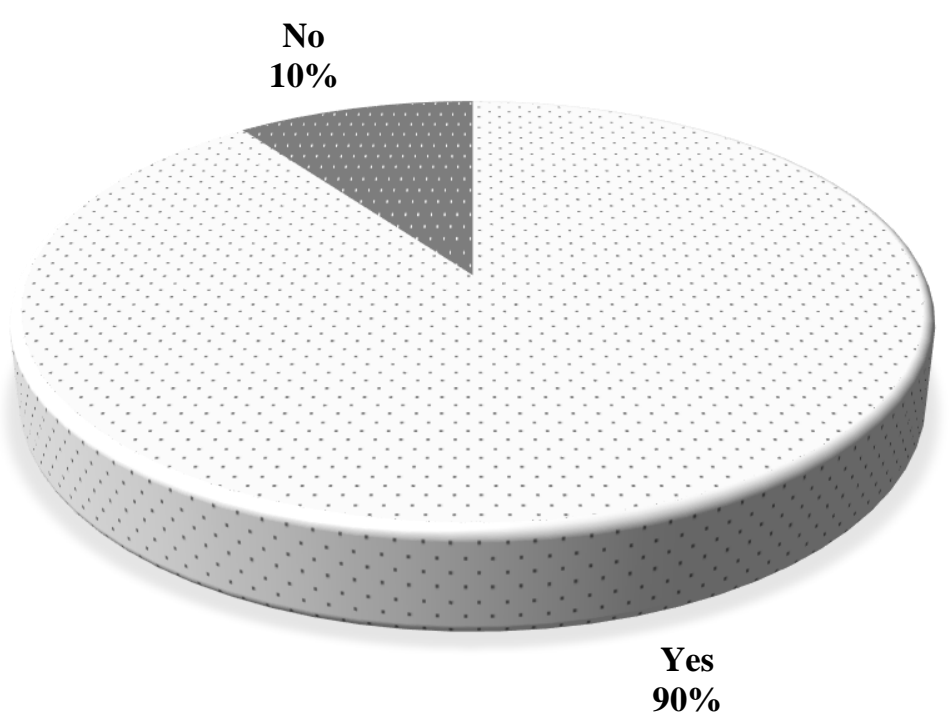

Figure 5.0 Percentage of Takaful Operators Audit on Adequacy of Shariah Governance Process Sources: (Researcher, 2020)

In terms of reviewing the Shariah governance process, normally auditors will refer to the requirement in Shariah governance framework, for example the duties of Shariah committee, Shariah review and other Shariah governance organs. Analysis shows that all operators perform audit on the adequacy of Shariah governance processes. However, one operator did not perform this audit. One of the respondents admitted that she did not know about this and asked the researcher to refer to the Board regarding this matter.

By checking the adequacy of Shariah governance process, it actually could give a very big impact because of the broad definition of Shariah governance. However, the minimum requirement that must be taken into consideration by the auditors is the existence of the four main functions as required in SGF; Shariah review, Shariah risk and management, Shariah research and development and Shariah function. Since there is no detailed explanation on this scope, majority of Takaful Operators just respond that they do check on the adequacy of Shariah governance process based on the requirements in SGF. Using the requirement in SGF as the benchmark to check on the Shariah governance process may be sufficient as this is the main guidelines for IFIs in Malaysia.

There are a few studies that have been conducted to examine on Shariah governance practice of Malaysian IFIs. This serves as a guide for the researcher to propose in detail the scope for Shariah governance that should be established by Takaful Operators. Table 4.0 provides the details of the scope that could be added up by the auditors in the future. 
Table 4.0 Proposed Scope for Adequacy of Shariah Governance Process

\begin{tabular}{ll}
\hline No. & Issues \\
\hline $\mathbf{1}$ & Role of Shariah Committee, Shariah review and Shariah auditor \\
& Establish governance structure \\
A written policy that sets out the SC members' appointment, composition, \\
selection and dismissal. \\
Supervisory and advisory roles of SC \\
Independency of SC \\
A written policy on Shariah review procedures, quality assurance and the \\
report \\
Access to all records, transactions and information \\
Charter that specifies the purpose, authority, and responsibility of the Shariah \\
audit \\
Effectiveness of Shariah governance \\
Notifications of Shariah committee meetings to board \\
Sufficient Shariah research conducted \\
Shariah risk management performed by risk officer \\
Findings of Shariah review must be communicated to SC \\
The officers conducting each Shariah compliance function are qualified and \\
capable \\
Exercise full disclosure and transparency on all issues deliberated in SC \\
meeting \\
Role of management \\
Being responsible for providing training and learning programs to internal \\
stakeholders \\
notifying the BNM and SC on any potential and actual Shariah non-compliance \\
events or activities and ensuring the correct rectification measures can be \\
taken into action immediately \\
Providing sufficient staff \\
Being transparent by providing accurate information to the SC
\end{tabular}

Sources: (Hidayat \& Khalifa, 2018; Yussof et al., 2014; Harun \& Abdullah, 2017)

It is very important for auditors to include those elements in their audit scope as it portrays the overall Shariah governance of the Takaful Operators. Having good Shariah governance would help in boosting the integrity of Takaful Operators, enhancing stakeholders' confidence, and reducing Shariah non-compliance risk which indirectly can contribute towards maintaining financial stability. 


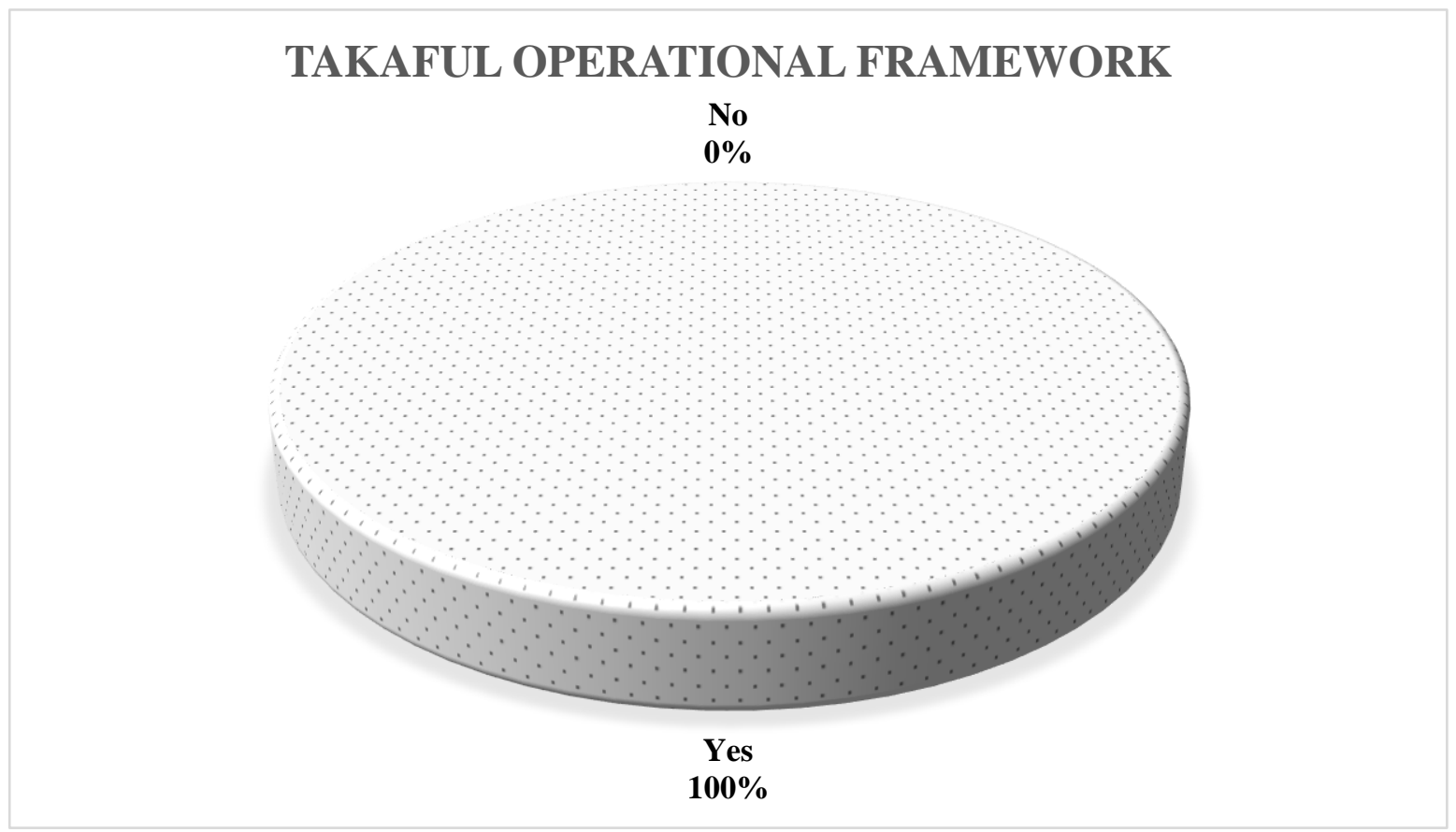

Figure 6.0 Percentage of Takaful Operators which Developed Their Audit Scope based on TOF Sources: (Researcher,2020)

Based on the analysis from the chart, all operators cover the requirement in TOF when performing Shariah audit exercise. But, it will be covered based on the audit cycle which means it is not covered during every financial year. This is the response from R11:

"Of course all of these cannot be covered in one year. We have an audit cycle. So of course, when we talk about audit cycle, we have to look at the risk. For every two years. All these depends on our yearly assessment". (R11)

On the other hand, R14 response was as follows:

"For every audit that we would like to perform, let's say we want to do audit on claims management because we have claims as one of our audit universe. We need to cover it once in three years' time. Thus, during the audit, we need to refer to this TOF and see what is the requirement related to claims. Another example is Retakaful. So, we will refer to TOF and see all the requirements. However, I remember last time, we did a comprehensive review on the requirement by TOF. So actually, it depends on our audit universe. Based on the audit universe, we need to identify the relevant guidelines." (R14)

On the same ground, R8 mentioned that they don't have any pending issues pertaining to all the requirement in TOF and SGF. Hence, they consider themselves to be on track and have fulfilled all the regulators' requirements. The auditor also emphasized that the audit scope will be based on their audit cycle and audit universe. 
MANAGEMENT SCIENCES

Vol. 11, No. 3, 2021, E-ISSN: 2225-8329 @ 2021 HRMARS

For Takaful Operator F, their auditor's response was as follows:

"When referring to the requirement in TOF, it is more towards operations and very general in terms of Shariah. There are a few things that were not covered and mentioned in TOF. For example, claims management. In claims management, TOF did not mention on the issues of ex-gratia payment. So, in this case, the organization, or we as Shariah auditors have to come out with one control for ex-gratia...or limitation. To whom can we pay? In what situation do we have to approve? These matters were not discussed in TOF and also the control. Another example is Retakaful commission. Let's say, a Takaful operator cannot cover a huge risk, and the operator gets the capital from their parent company which also provides conventional products. So, the commission came from a non-Takaful company and it should be a noncompliance risk issue from the income received. This is also not discussed in TOF". (R10)

Based on the above interview result, it is found that all operators always refer to TOF and the auditors always check on the level of compliance of operators to this TOF. Although, the level of compliance will not be checked every year because of time constraints and limited of resources, they have audit cycle which can help to ensure the comprehensiveness of the audit scope covered. Audit cycle also is related to risk-based approach. For example, for consecutive years, if there is a potential of risk on claims management, then the auditors would go for that scope in detail.

This TOF is the main reference for the operational part of Takaful Operators and failing to comply with those stipulated requirements would give a big impact to the Takaful Operators. Takaful Operators might be facing Shariah non-compliance risk, reputational risk and regulatory risk if they are not able to comply with requirements in the TOF. Thus, it can be concluded that the auditors did establish the requirement in TOF as the scope in conducting Shariah audit.

\section{RQ2. What should be included in the scope based on the perceptions of the Takaful players?}

In order to enhance the current practice, majority of Shariah committee agreed that the scope of Shariah audit should be widened. Among the suggested areas of scope that must be included when conducting Shariah audit besides the items suggested in SGF includes audit on the agent which can be considered as a marketing strategy, Shariah governance and so on. Although majority of Takaful Operators have successfully followed the suggested requirements of the scope that should be covered when performing Shariah audit function, some of them still did not include auditing financial statements as their audit scope because the financial statement part has been covered by the external auditor. The issue here is to what extent an external auditor could cover on Shariah issues in financial statements as we know that normally external auditors would just touch on the operation part when performing audit on financial statements.

A study done by Ab Ghani and Abdul Rahman (2015) indicates that only 55.5\% of the respondents have established audit of financial statements as part of their internal Shariah audit and this practice mostly comes from full-fledged Islamic banking. This result is quite similar with this study which found that only several Takaful Operators cover financial statements when performing Shariah audit function. The others would just let the external auditor audit their financial statements without bothering on what is the Shariah element that should be checked out in their financial statements. 
MANAGEMENT SCIENCES

Vol. 11, No. 3, 2021, E-ISSN: 2225-8329 @ 2021 HRMARS

Other than widening the scope, the function of Shariah audit also should be broadened up rather than just monitoring the compliance. As stated by Dr Daud Bakar during INTAC Seminar series II on the topic of "Comply or face consequences" that IFIs as a whole should move beyond compliance to be more visible and transparent in providing information to the public. He then added:

"It is not just meeting the requirement to ensure Shariah compliance in products, people, system and environment. What's more is the IFIs must be seen as 'whiter than white' and be able to articulate the reason behind Shariah compliance and non-compliance".

The above statement shows that Takaful Operators should think out of the box to improve their practices and at the same time enhancing their transparency to increase public confidence. Figure 7.0 below illustrates the scope that should be included in the shariah audit based on the perceptions of the industry.

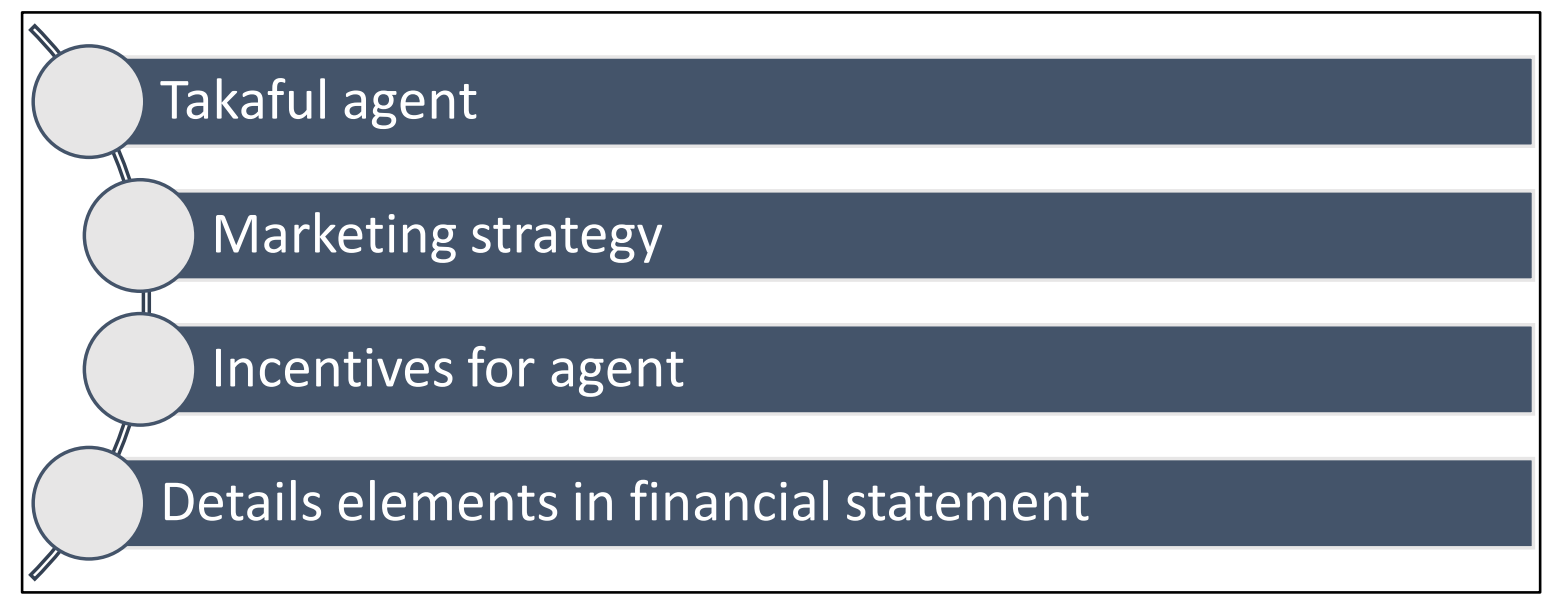

Figure 7.0 Expectation of the scope for shariah audit

Sources: (Researcher,2020)

\section{Conclusions and Recommendations}

Based on the findings, mostly all Takaful Operators manage to cover the proposed Shariah audit scope except for the area of financial statements. The main reason why some Takaful Operators include financial statements as the Shariah audit scope is because they rely on external auditors to audit their financial statements. SGF has also mentioned that the auditor can exclude financial statements from their Shariah audit scope provided that it has been audited by external auditors. Relying only on external auditors might lead to the failure to see any potential Shariah non-compliance risk in the financial statements.

This is because external auditors have different objectives when auditing financial statements. Normally, the external audit process ensures that the internal controls, procedures, protocols, and policies of an organization are sufficient, efficient, and in compliance with government requirements, industry standards, and corporate policies. External auditors are not focusing on the Shariah risk as their objectives are associated with the operational aspect only whereas in financial statements, there are also certain areas that are considered as Shariah key risk. For example, in reporting for claims and surplus. Thus, in order to enhance the effectiveness of the Shariah audit, the scope of financial statements should be developed by Shariah auditors. 
MANAGEMENT SCIENCES

Vol. 11, No. 3, 2021, E-ISSN: 2225-8329 (c 2021 HRMARS

This study has several limitations, much like most other empirical research. First, since this study only provides insightful knowledge from auditors and shariah committee, it is limited in generalizing the perspectives of all Takaful Operators' main stakeholders. As a result, more perspectives and viewpoints are needed in a comprehensive debate on Shariah audit practices of Takaful Operators. Secondly, the scope of the study is limited to Malaysian Takaful Industry only. Due to that, the practice of other types of Islamic Financial Institutions would not be discussed in this study. Third, this study does not take into account the viewpoints of policymakers such as Bank Negara Malaysia, which leaves potential for further research. Future research could look into policymakers' views on the issue. Future research could also evaluate the effectiveness of present audit processes using standards from the finance industry, particularly the Takaful industry. Despite its limitations, the study's findings are critical for Takaful players in enhancing present Shariah auditing practices.

\section{References}

Ab Ghani, N. L., Ariffin, M. N., \& Abdul Rahman, A. R. (2019). The Measurement of Effective Internal Shariah Audit Function in Islamic Financial Institutions. International Journal of Economics, Management and Accounting, 27(1), 141-165.

Ab. Rahim, F., \& Amin, H. (2011). Determinants of Islamic Insurance Acceptance: An Empirical Analysis. International Journal of Business and Society, 12(2), 37-54.

Abd. Ghani, N. L., \& Rahman, A. R. A. (2015). An analysis of Shari' ah audit practices in Islamic banks in Malaysia. Jurnal Pengurusan, 43, 107-118.

Abdul Rahman, N. H., Matsuki, N., Kasim, N., \& Osman, M. R. (2018). Risk Based Internal Shariah Audit Practices in the Islamic Bank. The Journal of Social Sciences Research,5, 954-961.

Abdul Razak, M. Z., \& Omar, N. (2008). Audit syariah dalam Instisusi Kewangan di Malaysia. Jurnal Muamalat, 1 (1), 135-150.

Abu Kasim, N. A. (2012). Disclosure of Shariah compliance by Malaysian Takaful companies. Journal of Islamic Accounting and Business Research, 3(1), 20-38.

Alahmadi, H. A., Hassan, A. F. S., Karbhari, Y., \& Nahar, H. S. (2017). Unravelling shariah audit practice in Saudi Islamic Banks. International Journal of Economic Research, 14(15), 255269.

Alexis, O., \& Vydelingum, V. (2004). The lived experience of overseas black and minority ethnic nurses in the NHS in the south of England. Diversity in Health and Social Care, 1, 13-20.

Algabry, L., Alhabshi, S. M., Soualhi, Y., \& Othman, A. H. A. (2020).Assessing the effectiveness of internal Sharīah audit structure and its practices in Islamic financial institutions: a case study of Islamic banks in Yemen. Asian Journal of Accounting Research.

Algabry, L., Alhabshi, S. M., Soualhi, Y., \& Othman, A. H. A. (2021. Assessing the effectiveness of internal Sharīah audit structure and its practices in Islamic financial institutions: a case study of Islamic banks in Yemen. Asian Journal of Accounting Research, 6(1), 2-22.

AlNemer, H. A. (2015). Participants' Satisfactions About Takaful Products \& Services: An Empirical Study on Saudi Arabia. International Journal of Business, Economics and Law, $7(1), 54-66$.

Billah, M. M., \& Basodan, Y. A. (2017). Islamic Insurance (Takaful) Models and Their Accounting Dichotomy. Journal of Islamic Banking and Finance, 1(3), 11-31.

Dikko, M. (2014). An Analysis of Issues in Takaful (Islamic Insurance). European Journal of Business and Management, 6 (15), 1-6. 
MANAGEMENT SCIENCES

Vol. 11, No. 3, 2021, E-ISSN: 2225-8329 @ 2021 HRMARS

Ginena, K. (2014). Shariah risk and corporate governance of Islamic banks. Corporate Governance, 14(1), 86-103.

Harun, H., \& Abdulalh, N. I. (2017). Enhancing the shariah governance framework for Malaysian IFIs through effective management strategies. International Journal of Public Finance, 2 (1), 63-80.

Hassan, H. A. (2019). Takaful Models: Origin, Progression and Future. Journal of Islamic Marketing, 11 (6), 1-19.

Hidayat, S. E., \& Al-Khalifa, A. K. (2018). Sharia Governance Practices at Islamic Banks in Bahrain From Islamic Bankers' Perspective. Journal of Islamic Economics, 10(1), 53-74.

Irkhami, N. (2017). A Study on the Implementation of Dual Contracts of Tabarru' and Tijarah on Shari'ah Insurance Industries in Indonesia. Journal of Islamic Finance, 6 (2), 45-57.

Kasim, N., Htay, S. N. N., \& Salman, S. A. (2015). Risk-Sharing and Shared Prosperity Through Takaful. Middle-East Journal of Scientific Research ,23 (11),2713-2721.

Kassim, N., \& Sanusi, Z. M. (2013). Emerging issues for auditing in Islamic Financial Institutions: Empirical evidence from Malaysia, Journal of business and management, 8(5), 10-17.

Kassim, N., \& Sanusi, Z. M. (2013). Emerging issues for auditing in Islamic Financial Institutions: Empirical evidence from Malaysia, Journal of business and management, 8(5), 10-17.

McLellan, E., MacQueen, K. M., \& Neidig, J. L. (2003).Beyond the qualitative interview: data preparation and transcription. Field Methods, 15(1),63-84.

Merriam, S. B. (2009). Qualitative Research: A Guide to Design and Implementation: Revised and Expanded from Qualitative Research and Case Study Applications in Education, Jossey-Bass, San Franscisco.

Puad, M. N. A., Shafii, Z., \& Abdullah, N. I. (2020). The Practices of Risk-Based Internal Shariah Auditing Within Malaysian Takaful Operators: A Multiple Case Study. International Journal of Academic Research in Business and Social Sciences, 10(7), 52-71.

Ali, M. N. A., \& Shafii, Z. (2014). The Undergraduates ' Perspective on Shariah Audit in Islamic Banks : An Insight to the Future Shariah Auditor Labour Market in Malaysia, Procedia - Social and Behavioral Sciences, 18(1), 1-20.

Fauzi, M. P. N. F. N., Abdul Rashid, K., Sharkawi, A. A., Hasan, A. F., Aripin, S., \& Arifin, M. A. (2016). Takaful: A review on performance, issues and challenges in Malaysia. Journal of Scientific Research and Development, 3 (4),71-76.

Noor, M. A. (2009). A Shariah Compliance Review on Investment Linked Takaful in Malaysia. Islamic Economic Studies, 17(1), 1-20.

Muhamat, A. A., Jaafar, M. Z., \& Alwi, S. F. (2017). General Takaful claims: An experience of Takaful operator in Malaysia. Journal of Emerging Economies \& Islamic Research, 5(4) ,18- 26.

Nahar, H. S. (2015). Insurance vs Takaful: Identical sides of a coin. Journal of Financial Reporting and Accounting, 13(2), 247-266.

Noordin, K. B. (2013).The Management of Underwriting Surplus by Takaful Operators in Malaysia. Retrieved from https://pdfs.semanticscholar.org/f124/1b720cc17a93eab1a1814eb789aae3915ce9.pd f?_ga $=2.226150810 .1047494242 .1566180797-288516192.1565441473$

Saha, A. (2010). Takaful surplus distribution: A different perspective. Islamic Finance News. December 2010.

Shafii, Z., Salleh, S., Mustafa, H., Hanefah, M., \& Jusoff, K. (2013). Human Capital Development in Shariah Audit. Middle East journal of scientific research.28-34 
Swartz, N., \& Coetzer, P. (2010). Takaful: An Islamic insurance instrument. Journal of development and agricultural economics, 2, 333-339.

Weischedel, B., Matear, S., \& Deans, K. R. (2005). A qualitative approach to investigating online strategic decision making. Qualitative Market Research: An International Journal, $8(1), 61-76$.

Yaacob, H., \& Donglah, N. K. (2012). Shari'ah Audit in IFIs: The Postgraduates' Perspective. International Journal of Economics and Finance, 4(12), 224-239.

Yaacob, H., Shafeek, F., \& Nahar, H. S. (2013). Exploring Undergraduate Students' Understanding of Shari'ah Based Audit: Implications for the Future of Shari' ah Auditing Labor Market in Brunei. Asian Journal of Finance \& Accounting, 5(2), 84-100.

Yazkhiruni, Y., Nurmazilah, M., \& Haslida, A. H. (2018). A Review of Shariah Auditing Practices in Ensuring Governance in Islamic Financial Institution(IFIs)-A Preliminary Study. Advances in Social Sciences Research Journal,5(7), 196-210.

Yusoff, A., Othman, A. A., Arifin, M., Napiah, M. D., Hassan, R., \& Omar, M. N. (2014). An Empirical Study of the Effectiveness of the Shariah Governance Framework (SGF 2011). ISRA Research paper.

Zakaria, N., Ariffin, N. M., \& Abidin, N. (2019). Internal Shariah Audit Effectiveness and its Determinants: Case of Islamic Financial Institutions in Malaysia. Kyoto Bulletin of Islamic Area Studies, 12, 8-28. 